\title{
PENGARUH PERHATIAN ORANG TUA TERHADAP KREATIVITAS BELAJAR PESERTA DIDIK DI MTS MUHAMIMADIYAH JULUBORI KECAMATAN PALANGGA KABUPATEN GOWA
}

\author{
H. Muh. Sain Hanafy \\ Fakultas Tarbiyah dan Keguruan \\ Universitas Islam Negeri Alauddin Makassar \\ Jl. H. M. Yasin Limpo No. 36 Samata, Gowa

\section{Nikawati} \\ Fakultas Tarbiyah dan Keguruan \\ Universitas Islam Negeri Alauddin Makassar \\ J1. H. M. Yasin Limpo No. 36 Samata, Gowa
}

\begin{abstract}
This study aims to obtain a description of the attention of parents of learners in MTs Muhammadiyah Julubori and creativity of learning in MTs Muhammadiyah Julubori and the influence of parents' attention on the creativity of learners in MTs Muhammadiyah Julubori. This type of research is quantitative research with ex-postfacto approach. The population in this study were all students in MTs Muhammadiyah Julubori Kecamatan Palangga Gowa District with the number of 131 people while the sample is $25 \%$ of all students in MTs Muhammadiyah Julubori as many as 33 students and their parents respectively so that the total sample to 66 taken through simple random sampling technique. The instrument used in this study is a questionnaire. The analysis technique used is descriptive statistical analysis and inferential statistical analysis with simple regression analysis technique. Based on the results of data analysis using descriptive statistics, then: (1) attitudinal attitude of parents learners obtained an average value of 33.64 are in the medium category, creativity learners learners obtained average value 28.64 is in the category of being, and the result of simple regression analysis between attitude of parents attention to creativity learners learn significant value > 0,05 (0,064) because significant value bigger than 0,05 hence can be concluded that attention of parent have no effect to creativity learn. Learning creativity is the potential of every learner, let every educational institution able to help learners to develop creativity that is owned well.
\end{abstract}

Keywords: Attention, Creativity, and Learning

\section{LATAR BELAKANG}

$\mathrm{P}$ endidikan di dalam keluarga pada hakikatnya merupakan proses pendidikan sepanjang hayat. Pembinaan dan pengembangan kepribadian dilakukan melalui pengalaman hidup sehari-hari dan dipengaruhi oleh sumber belajar yang ada di keluarga, utamanya orang tua. Proses pendidikan dalam keluarga disebut sebagai pendidikan yang pertama dan utama, karena ia menjadi peletak pondasi kepribadian 
anak. $^{1}$

Berdasarkan penjelasan di atas, Segala sesuatu yang diperbuat di keluarga dapat mempengaruhi anak, begitupun sebaliknya. Keluarga memberikan dasar pembentukan tingkah laku, watak, moral, dan pendidikan kepada anak. Pengalaman interaksi di dalam keluarga akan menentukan pola tingkah laku anak terhadap orang lain dalam masyarakat. Sehingga orang tua dituntut bahkan dikenai kewajiban untuk mengasuh anak-anak mereka dengan menggunakan pengasuhan yang tepat.

Tugas orang tua untuk mendidik keluarga khusus anak-anaknya, secara umum Allah swt. tegaskan dalam QS at-Tahrim/66: 6.

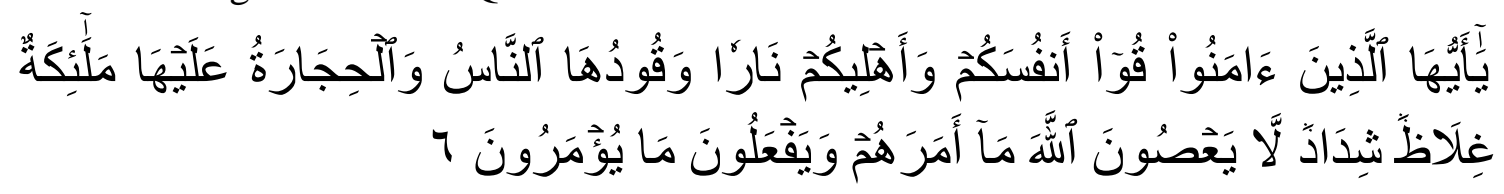

Terjemahnya:

Hai orang-orang yang beriman, peliharalah dirimu dan keluargamu dari api neraka yang bahan bakarnya adalah manusia dan batu; penjaganya malaikat-malaikat yang kasar, keras, dan tidak mendurhakai Allah terhadap apa yang diperintahkan-Nya kepada mereka dan selalu mengerjakan apa yang diperintahkan. ${ }^{2}$

Ayat di atas menggambarkan bahwa dakwah dan pendidikan harus bermula di rumah. Secara redaksi ayat tersebut tertuju kepada lelaki (ayah), tetapi itu bukan berarti hanya tertuju kepada mereka. Akan tetapi, ayat ini juga ditujukan kepada perempuan dan lelaki (ayah dan ibu). Ini berarti kedua orang tua bertanggung jawab terhadap anakanak dan pasangan masing-masing.

Pada umumnya pendidikan dalam rumah tangga itu bukan berpangkal tolak dari kesadaran dan pengertian yang lahir dari pengetahuan mendidik, melainkan karena secara kodrati suasana dan strukturnya memberikan kemungkinan alami membangun situasi pendidikan. Situasi pendidikan itu terwujud berkat adanya pergaulan dan hubungan pengaruh mempengaruhi secara timbal balik antara orang tua dengan anak. ${ }^{3}$

Berdasarkan hal di atas, pendidikan di keluarga orang tua mampu menciptakan suasana yang baik tanpa adanya tekanan, paksaan, dan kekerasan. Pola didik seperti itu hanya akan membawa pertentangan antara orang tua dengan anaknya. Terkadang antara anak dan orang tua sering kali berbeda pendapat dan selera dalam pemilihan lembaga pendidikan. Sehingga menimbulkan perselisihan dan terkadang terkesan memaksa kehendak, baik kehendak dari orang tua terhadap anak maupun sebaliknya. Pada hakikatnya, tentu kita ketahui bahwa setiap orang tua ingin selalu yang terbaik untuk

\footnotetext{
${ }^{1}$ M. Ismail Yusanto, dkk., Menggagas Pendidikan Islam (Cet. IV; Bogor: Al Azhar Press, 2014), h. 78 .

${ }^{2}$ Departemen Agama RI. Al-Quran dan Terjemahannya (Cet X; Bandung: Diponegoro, 2010), h. 560.

${ }^{3}$ Zakiah Drajat, Ilmu Pendidikan Islam (Cet. III; Jakarta: Bumi Askara, 1996), h. 36.
} 
anak- anaknya. Akan tetapi terkadang mereka tidak memahami apakah yang terbaik menurutnya terbaik pula untuk anak-anaknya. Maka dari itu, orang tua mempertimbangkan dengan baik dalam pemberian stimulus agar anak mampu meresponnya dengan baik pula.

Kreativitas berarti jauh lebih banyak daripada bakat dalam seni atau musik. Kreativitas meliputi keseluruhan jajaran pemikiran yang kreatif dan kepetualangan pada setiap bidang: penemuan ilmu pengetahuan, imajinasi, rasa ingin tahu, penyelidikan, percobaan, dan penemuan. Kreativitas adalah kemampuan untuk memulai ide, melihat hubungan yang baru, dan tak diharapkan untuk merumuskan konsep ketimbang menghafal, untuk menemukan jawaban atas masalah dan pertanyaan baru yang untuk dicari jawabannya. ${ }^{4}$

Setiap anak pada dasarnya memiliki potensi kreatif. Beberapa di antaranya memiliki potensi lebih dari yang lain terutama pada usia sekolah. Oleh karena itu, keluarga sebagai lembaga pendidikan pertama mampu mendorong setiap anak untuk mengembangkan kreativitasnya.

Di MTs Muhammadiyah Julubori Kecamatan Palangga Kabupaten Gowa dengan pola asuh yang beragam memiliki kreativitas yang beragam pula. Hal ini terlihat dari kreativitas anak berkembang sangat baik dimana para peserta didik mampu berimajinasi, mandiri dalam berpikir, penuh energi, dan percaya diri saat di sekolah. Akan tetapi, kreativitas belajar tersebut hanya terjadi pada sebagian peserta didik. ${ }^{5}$

Berdasarkan hal di atas, mendorong penulis untuk melakukan penelitian mengenai pengaruh perhatian orang tua terhadap kreativitas belajar peserta didik di MTs Muhammadiyah Julubori Kecamatan Palangga Kabupaten Gowa.

\section{KAJIAN TEORI}

\section{A. Perhatian}

Perhatian adalah keaktifan jiwa yang diarahkan kepada suatu objek, baik di dalam maupun diluar dirinya. Pemusatan kesadaran jiwa terhadap sesuatu objek berarti tidak semua unsur/objek yang bersamaan timbul menjadi sasaran kesadaran, tetapi ada sebagian unsur-unsur/objek yang dikesampingkan. ${ }^{6}$

Makin kuat kosentrasi jiwa, makin cepat lenyapnya unsur-unsur yang tidak menjadi sasaran dari lingkungan kesadaran. Objek yang menjadi sasaran mungkin halhal yang ada di dalam dirinya sendiri, misalnya: tanggapan, pengertian perasaan, dan sebagaimana mungkin hal-hal yang berada di luar dirinya, misalnya: keadaan alam,

\footnotetext{
${ }^{4}$ Joan Beck, Asih Asah Asuh (Cet. IV; Semarang: Dahara Prize, 1992), h. 160.

${ }^{5}$ Muhammad Saad, Kepala MTs Muhammadiyah Julubori Gowa, Wawancara, Gowa, 20 Februari

${ }^{6}$ Abu Ahmadi, Psikologi Umum (Cet. I; Jakarta: PT Rineka Cipta,1992), h. 145.
} 2017. 
keadaan masyarakat, sosial ekonomi, dan sebagainya. ${ }^{7}$

Relasi antar anggota keluarga yang terpenting adalah relasi orang tua dengan anaknya. Selain itu relasi anak dengan saudaranya atau dengan anggota keluarga yang lain pun turut mempengaruhi belajar anak. Wujud relasi itu misalnya apakah hubungan itu penuh dengan kasih sayang dan pengertian, ataukah diliputi oleh kebencian, sikap yang terlalu keras ataukah sikap acuh tak acuh dan sebagainya. Begitu juga jika relasi anak dengan saudaranya arau dengan anggota keluarga lain tidak baik, akan dapat menimbulkan problem yang sejenis. ${ }^{8}$

Perhatian orang tua untuk meningkatkan semangat belajar anak juga terletak pada suasana rumah, suasana rumah yang dimaksudkan sebagai situasi atau kejadiankejadian yang sering terjadi di dalam keluarga di mana anak berada dan belajar. Suasana rumah merupakan juga merupakan faktor yang paling penting yang tidak termasuk faktor yang disengaja. Suasana rumah yang gaduh atau ramai dan semerawut tidak akan memberi ketenangan kepada anak yang belajar. Suasana tersebut dapat terjadi pada keluarga yang besar yang terlalu banyak penghuninya, suasana rumah yang tegang, ribut dan sering cekcok, pertengkaran antar anggota keluarga atau dengan keluarga lain menyebabkan anak menjadi bosan di rumah, suka keluar rumah, akibatnya belajarnya kacau. ${ }^{9}$

Faktor lainnya yaitu, keadaan ekonomi keluarga erat hubungannya dengan belajar anak. Anak yang sedang belajar selain harus terpenuhi kebutuhan pokoknya, misal makan, pakaian, perlindungan kesehatan dan lain-lain, juga membutuhkan fasilitas belajar seperti ruang belajar, meja, kursi, penerangan, alat tulis menulis, buku-buku dan lain-lain. Fasilitas belajar itu hanya dapat terpenuhi jika keluarga mempunyai cukup uang. Jika anak hidup dalam keluarga yang miskin, kebutuhan pokok anak kurang terpenuhi, akibatnya kesehatan anak terganggu sehingga belajar anak juga terganggu. ${ }^{10}$

Orang yang menaruh minat pada suatu aktivitas akan memberikan perhatian yang besar. Ia tidak segan mengorbankan waktu dan tenaga demi aktivitas tersebut. Oleh karena itu orang tua yang mempunya perhatian terhadap anaknya, pasti akan berusaha keras untuk memberikan yang terbaik bagi anaknya terkhusus pendidikan anaknya.

Dari beberapa pendapat di atas, dapat disimpulkan bahwa perhatian adalah suatu kegiatan yang merupakan sikap mental dan sosial, diarahkan dengan intensif, baik perkataan maupun perbuatan.

\footnotetext{
${ }^{7}$ Abu Ahmadi, Psikologi Umum, h. 146.

${ }^{8}$ Slameto, Belajar dan Faktor-faktor yang Mempengaruhinya (Cet.III; Jakarta: PT Rineka Cipta

${ }^{9}$ Slameto, Belajar dan Faktor-Faktor yang Mempengaruhinya, h. 62.

${ }^{10}$ Slameto, Belajar dan Faktor-Faktor yang Mempengaruhinya, h. 63.
} 1995), h. 62. 


\section{B. Kreativitas}

Kreativitas tidak terbatas pada kemampuan dalam bidang menulis dan keilmuankeilmuan akademis. Kreativitas mencakup semua dimensi kehidupan dan tidak hanya terbatas pada kemampuan-kemampuan akademis, seperti yang dipahami kebanyakan orang. ${ }^{11}$

Kreativitas berarti jauh lebih banyak dari pada bakat dalam seni atau musik. Kreativitas meliputi keseluruhan jajaran pemikiran yang kreatif dan kepetualangan pada setiap bidang: penemuan ilmu pengetahuan, imajinasi, rasa ingin tahu, penyelidikan, percobaan dan penemuan. Kreativitas adalah kemampuan untuk memulai ide, melihat hubungan yang baru tak diharapkan untuk merumuskan konsep ketimbang menghafal, untuk menemukan jawaban atas masalah dan pertanyaan baru yang untuk dicari jawabannya. ${ }^{12}$

Anak yang kreatif mempunyai intelegensi dari urutan tertinggi tetapi ia dapat atau tidak dapat memperoleh nilai yang baik dalam tes IQ yang pada pokoknya mengukur bidang kemampuan mental akademik. Riset pada kreativitas anak jauh dari sempurna dan kebanyakan dari apa yang diketahui telah dipelajari dalam studi anak usia sekolah. Tes kreativitas yang berlaku sulit dikembangkan, karena secara definisi tes tersebut berkaitan dengan menghasilkan banyak ide segar dan jalan keluar yang tak ortodoks daripada satu jawaban "benar". Sehingga tes sukar dinilai dan dievaluasi. ${ }^{13}$

Mengenali beragam kreativitas anak dari berbagai latar belakang masyarakat, orang tua, dan lembaga pendidikan sangat penting dalam rangka menumbuh kembangkannya. Hal tersebut nantinya akan menjadi pijakan bagi anak dalam membentuk kepribadiannya yang mampu menciptakan kehidupan yang dinamis. ${ }^{14}$

Dalam literatur filosois, Elliot menempatkan kreativitas sangat dekat dengan imajinasi. Ia menulis bahwa "kreativitas berkaitan dengan imajinasi atau manifestasi kecerdikan dalam beberapa pencarian yang bernilai". Ia tidak mengikatkan konsep kreativitas dengan produk akhirnya, namun hanya sebuah "pencarian" dengan kata lain, kepada proses. Jadi, bagi Elliot, proses yang dilakukan oleh beberapa orang dapat dianggap sebagai kreatif. Bagi Elliot proses yang termasuk dalam kreativitas adalah pemecahan masalah (problem solving) dan membuat sebuah ide. Ia mengklaim bahwa "melangkah secara imajinatif adalah bersikap kreatif. Semua kreativitas adalah kreatif (yakni pemikiran imajintif). ${ }^{15}$

\footnotetext{
${ }^{11}$ Muhammad Subhi Abdussalam, Langkah Mudah Gali Potensi Si Buah Hati, h. 52.

12 Joan Beck, Asih Asah Asuh, h. 160.

13 Joan Beck, Asih Asah Asuh, h. 160.

${ }^{14}$ Muhammad Subhi Abdussalam, Langkah Mudah Gali Potensi Si Buah Hati, h. 58.

15 Anna Craft, Me-Refresh Imajinasi dan Kreativitas Anak-Anak (Cet. I; London: Cerdas Pustaka,
} 2000), h. 10. 


\section{Belajar}

Belajar dapat didefinisikan sebagai suatu usaha atau kegiatan yang bertujuan mengadakan perubahan di dalam diri seseorang, mencakup perubahan tingkah laku, sikap, kebiasaan, ilmu pengetahuan, keterampilan, dan sebagainya. ${ }^{16}$

Islam menurut Dr. Yusuf Al- Qardhawi, adalah akidah yang berdasarkan ilmu pengetahuan, ${ }^{17}$ ini tersirat dalam firman Allah swt., QS Muhammad/ 47: 19.

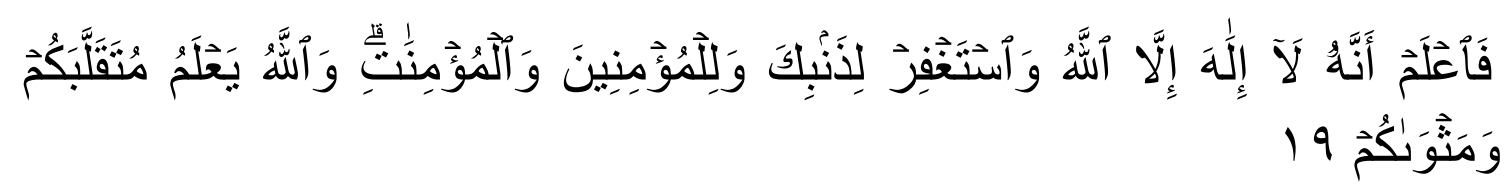

Terjemahnya:

Maka ketahuilah, bahwa Sesungguhnya tidak ada Ilah (sesembahan, Tuhan) selain Allah dan mohonlah ampunan bagi dosamu dan bagi (dosa) orang-orang mukmin, lakilaki dan perempuan. dan Allah mengetahui tempat kamu berusaha dan tempat kamu tinggal. ${ }^{18}$

Dari ayat di atas, dan kaitannya dengan belajar adalah belajar perlu diusahakan agar seseorang dapat mengadakan perubahan di dalam diri mencakup perubahan tingkah laku, sikap, kebiasaan, ilmu pengetahuan, keterampilan, dan sebagainya Belajar merupakan tindakan dan perilaku siswa yang kompleks. Laki-laki dan perempuan akan memeiliki derajat yang sama bila ketakwaannya sama di hadapan Allah, dan salah satu caranya adalah terus berusaha untuk belajar agar pantas disebut sebagai manusia yang bertakwa.

Sebagai tindakan, maka belajar hanya dialami oleh siswa itu sendiri. Siswa adalah penentu terjadinya atau tidak terjadinya proses belajar. Proses belajar terjadi berkat siswa memperoleh sesuatu yang ada dilingkungan sekitar. ${ }^{19}$

Menurut Gagne belajar merupakan kegiatan yang kompleks. Hasil belajar merupakan kapabilitas. Setelah belajar orang memiliki keterampilan, pengetahuan, sikap, dan nilai. Timbulnya kapabilitas tersebut adalah dari stimulasi yang berasal dari lingkungan, dan proses kognitif yang dilakukan oleh yang belajar. Dengan demikian, belajar adalah seperangkat proses kognitif yang mengubah sifat stimulasi, lingkungan, melewati pengelolaan informasi menjadi kapabilitas baru. ${ }^{20}$

${ }^{16}$ Dalyono, Psikologi Pendidikan (Cet. VII; Jakarta: Rineka Cipta, 2012), h. 49.

${ }^{17}$ Muhibbin Syah, Psikologi Belajar (Cet. V; Jakarta: Raja Grafindo Persada, 2006), h. 85.

${ }^{18}$ Departemen Agama RI. Al-Quran dan Terjemahannya (Cet X; Bandung: Diponegoro, 2010), h. 508.

${ }^{19}$ Dimyati dan Mudjiono, Belajar dan Pembelajaran (Cet. II; Jakarta: PT Rineka Cipta, 2002), h.

${ }^{20}$ Dimyati dan Mudjiono, Belajar dan Pembelajaran, h. 10. 
Dari uraian di atas dapat diketahui belajar adalah kegiatan manusia yang sangat penting dan harus dilakukan selama hidup, karena melalui belajar dapat melakukan perbaikan dalam berbagai hal yang menyangkut kepentingan hidup. Belajar tidak dapat dilakukan secara temporal namun harus terus berkesinambungan, karena hakikatnya dalam hidup ini segala sesuatunya harus dengan ilmu, bahkan sampai ajal menjelang.

\section{METODE PENELITIAN}

Jenis penelitian ini adalah penelitian kuantitatif dengan pendekatan ex-postfacto. Populasi dalam penelitian ini adalah seluruh peserta didik di MTs Muhammadiyah Julubori Kecamatan Palangga Kabupaten Gowa dengan jumlah 131 orang sedangkan sampelnya adalah 25\% dari seluruh peserta didik di MTs Muhammadiyah Julubori sebanyak 33 peserta didik beserta orang tuanya masing-masing sehingga total sampel menjadi 66 yang diambil melalui teknik simple random sampling. Instrumen yang digunakan dalam penelitian ini adalah angket Uji validitas menggunakan rumus korelasi product moment, pada variable perhatian orang tua terdapat 28 butir valid dan 21 butir tidak valid. Butir yang tidak valid dihapuskan dalam penelitian. validitas instrumen skala kreativitas belajar terdapat 29 butir valid dan 37 butir tidak valid. Butir yang tidak valid dihapuskan dalam penelitian. Uji reliabilitas menggunakan rumus Alpha Cronbach Indeks reliabilitas masing-masing instrumen, yaitu 0,846 untuk instrumen perhatian orang tua, dan 0,703 untuk kreativitas belajar peserta didik. Sehingga kedua variable dinyatakan reliable.

Uji prasyarat terdiri dari uji normalitas, uji multikolineritas, dan uji lineriatas menggunakan teknik Kolmogorov-Smirnov dengan bantuan SPSS versi 20.0. diperoleh nilai sig. 0, 265 untuk uji normalitas perhatian orang tua, dan 0,808 untuk kreativitas belajar. Uji multikolineritas diperoleh Nilai VIF untuk variabel perhatian Orang Tua nilai VIF sebesar 1,002 dan nilai tolerance sebesar 0,998 . hasil uji linieritas perhatian orang tua terhadap kreativitas belajar peserta didik diperoleh hasil sig. 0,624 > berarti persamaan regresi perhatian orang tua terhadap kreativitas belajar berupa garis linear.

\section{HASIL PENELITIAN}

\section{A. Gambaran Perhatian Orang Tua di MTs Muhammadiyah Julubori Kecamatan Palangga Kabupaten Gowa}

Penelitian yang telah dilakukan terhadap orang tua peserta didik kelas VII MTs Muhammadiyah Julubori Kecamatan Palangga Kabupaten Gowa yang berjumlah 33 orang tua siswa melalui instrumen penelitian berupa skala yang diisi oleh orang tua siswa. Skala yang diberikan tersebut kemudian diberikan skor pada masing-masing item yang tersedia. Skor perhatian orang tua peserta didik kelas VII MTs Muhammadiyah Julubori Kecamatan Palangga Kabupaten Gowa dapat dilihat pada lampiran.

Berikut ini adalah tabel hasil analisis deskriptif data perhatian orang tua peserta didik kelas VII MTs Muhammadiyah Julubori Kecamatan Palangga Kabupaten Gowa. 
Tabel 4.1: Descriptive Statistics Perhatian Orang Tua Peserta Didik Kelas VII MTs Muhammadiyah Julubori Kecamatan Palangga Kabupaten Gowa

\begin{tabular}{|c|c|}
\hline Statistik & Skor statistik \\
\hline Sampel & 33 \\
\hline skor terendah & 25 \\
\hline skor tertinggi & 39 \\
\hline Rerata & 33,64 \\
\hline Standar Deviasi & 3,050 \\
\hline
\end{tabular}

Sumber: Hasil Olah Data Angket Nomor VIII

Tebel 4.1 menggambarkan bahwa, perhatian orang tua peserta didik kelas VII MTs Muhammadiyah Julubori Kecamatan Palangga Kabupaten Gowa yang didapatkan melalui instrumen skala menunjukkan bahwa skor tertinggi 39 dan skor terendah adalah 25. Skor rerata yang diperoleh adalah 33,64. Sedangkan Standar deviasi sebesar 3,050.

Tabel distribusi frekuensi dan perhitungan data sikap peratian orang tua peserta didik kelas VII MTs Muhammadiyah Julubori Kecamatan Palangga Kabupaten Gowa dan akan disajikan dalam bentuk tabel berikut:

Tabel 4.2: Distribusi Frekuensi Perhatian Orang Tua Peserta Didik di MTs Muhammadiyah Julubori Kecamatan Palangga Kabupaten Gowa

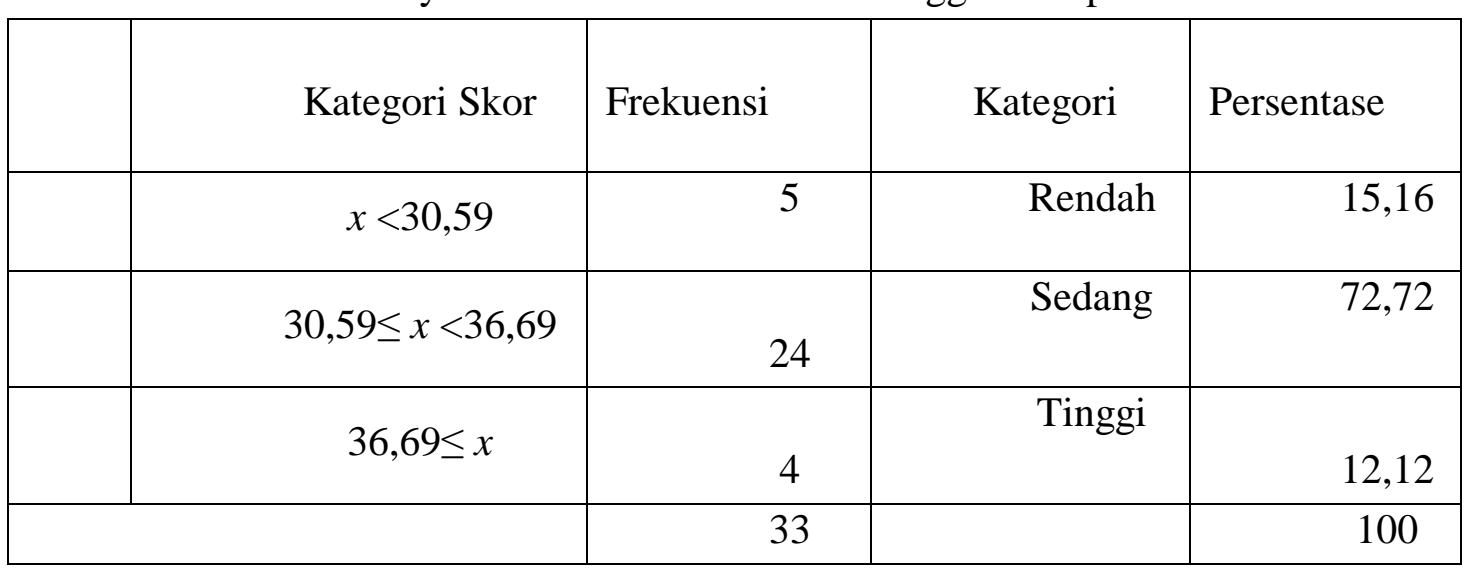

Tabel 4.2 menggambarkan bahwa, terdapat 5 orang tua peserta didik memiliki skor rendah dengan persentase 15,16\%, 24 orang tua peserta didik memiliki perhatian sedang dengan persentase $72,72 \%$, dan 4 orang tua peserta didik memiliki perhatian tinggi dengan persentase $12,12 \%$. Dengan demikian dapat disimpulkan bahwa skor perhatian orang tua pada seluruh subjek penelitian ini termasuk kategori cukup.

\section{B. Gambaran Kreativitas Belajar Peserta Didik Kelas VII di MTs Muhammadiyah Julubori Kecamatan Palangga Kabupaten Gowa}

Hasil penelitian yang telah dilakukan terhadap terhadap peserta didik kelas VII di MTs Muhammadiyah Julubori Kecamatan Palangga Kabupaten Gowa yang berjumlah 33 siswa melalui instrumen penelitian berupa skala yang diisi oleh siswa. Skala yang diberikan tersebut kemudian diberikan skor pada masing-masing item yang tersedia. 
Skor kreativitas belajar peserta didik di MTs Muhammadiyah Julubori Kecamatan Palangga Kabupaten Gowa dapat dilihat pada lampiran.

Berikut ini adalah tabel hasil analisis deskriptif data kreativitas belajar peserta didik di MTs Muhammadiyah Julubori Kecamatan Palangga Kabupaten Gowa.

Tabel 4.7: Descriptive Statistics Kreativitas Belajar Peserta Didik di MTs

Muhammadiyah Julubori Kecamatan Palangga Kabupaten Gowa

\begin{tabular}{|c|c|}
\hline Statistik & Skor statistik \\
\hline Sampel & 33 \\
\hline skor terendah & 22 \\
\hline skor tertinggi & 36 \\
\hline Rerata & 28,64 \\
\hline Standar Deviasi & 3,543 \\
\hline
\end{tabular}

Sumber: Hasil Olah Data Angket Nomor VIII

Tabel 4.7 menggambarkan bahwa, kreativitas belajar peserta didik di MTs Muhammadiyah Julubori Kecamatan Palangga Kabupaten Gowa yang didapatkan melalui instrumen skala menunjukkan bahwa skor tertinggi 36 dan skor terendah adalah 22, Skor rerata yang diperoleh adalah 28,64. Sedangkan Standar deviasi sebesar 3,543.

Berdasarkan data tabel di atas selanjutnya menyusun tabel distribusi frekuensi dan perhitungan data kreativitas belajar peserta didik di MTs Muhammadiyah Julubori Kecamatan Palangga Kabupaten dan akan disajikan dalam bentuk tabel berikut:

Tabel 4.8: Distribusi Frekuensi Kreativitas Belajar Peserta Didik di MTs Muhammadiyah Julubori Kecamatan Palangga Kabupaten Gowa.

\begin{tabular}{|l|c|c|r|r|}
\hline o & Kategori Skor & Frekuensi & Kategori & Persentase \\
\hline & $x<25,09$ & 6 & Rendah & 18,18 \\
\hline & $25,09 \leq x<32,18$ & 21 & Sedang & 63,64 \\
\hline & $32,18 \leq x$ & 6 & Tinggi & 18,18 \\
\hline & 33 & & 100 \\
\hline
\end{tabular}

Tabel 4.8 menggambarkan bahwa, terdapat 6 orang peserta didik memiliki kreativitas belajar rendah dengan persentase 18,18\%, 21 peserta didik memiliki kreativitas belajar sedang dengan persentase 63,64\%, dan 6 peserta didik memiliki kreativitas belajar tinggi dengan persentase 18,18\%. Dengan demikian dapat disimpulkan bahwa skor perhatian orang tua pada seluruh subjek penelitian ini termasuk kategori cukup. 


\section{Pengaruh Perhatian Orang Tua Terhadap Kreativitas Belajar Peserta Dididk Di MTs Muhammadiyah Kecamatan Palangga Kabupaten Gowa}

Analisis regresi linier sederhana ini digunakan untuk mengetahui pengaruh perhatian orang tua terhadap kreativitas belajar peserta didik di MTs Muhammadiyah Julubori Kecamatan Palangga Kabupaten Gowa.

Hasil analisis regresi linier sederhana dengan menggunakan SPSS 20.0 sebagai berikut:

Tabel 4.14: Analisis Regresi Perhatian Orang Tua terhadap Kreativita Belajar

\begin{tabular}{|c|c|c|c|}
\hline Variabel & B & T & Sig. \\
\hline Konstan & $7^{15,90}$ & $2^{2,38}$ & 0,023 \\
\hline Perhatian Orang Tua & 0,378 & $8^{1,91}$ & 0,064 \\
\hline
\end{tabular}

Sumber: Hasil Olah Data Angket Nomor XII

Tabel 4.14 menggambarkan bahwa, model persamaan regresi sederhana untuk memperkirakan kreativitas belajar peserta didik yang dipengaruhi oleh sikap perhatian orang tua adalah:

$$
Y=15,907+0,378 X
$$

$\mathrm{Y}$ adalah kreativitas belajar, $\mathrm{X}_{1}$ adalah perhatian orang tua. Dari persamaan di atas, dapat di analisis beberapa hal antara lain:

Koefisien regresi sederhana sebesar 0,378 mengindikasikan bahwa besaran penambahan tingkat kreativitas belajar peserta didik setiap pertambahan jawaban orang tua siswa untuk variabel perhatian orang tua.

Berdasarkan aplikasi analisis SPSS 20.0 diperoleh kesimpulan hasil analisis yaitu sebagai berikut:

Tabel 4.15: Korelasi Perhatian terhadap Kreativitas Belajar

\begin{tabular}{|l|rr|r|r|r|}
\hline Regresi & & $\mathrm{R}$ & $\mathrm{R}^{2}$ & $\mathrm{~F}$ & Sig. \\
\hline $\mathrm{X}_{1} \mathrm{Y}$ & & 0, & 0,10 & 3,6 & 0,0 \\
& 326 & & 6 & 81 & 64 \\
\hline
\end{tabular}

Sumber: Hasil Olah Data Angket Nomor XII

Berdasarkan hasil analisis diperoleh nilai $\mathrm{R}$ sebesar 0,326. Hal ini menunjukkan bahwa tidak terjadi hubungan antara perhatian orang tua terhadap kreativitas. Berdasarkan hasil perhitungan di atas dan analisis menggunakan SPSS 20.0 diperoleh nilai signifikansi sebesar Sig $=0,064$ dengan kofisien korelasi sebesar $r=0,326$. Karena nilai Sig $>\alpha(0,064>0,05)$ maka dapat dikatakan bahwa perhatian orang tua tidak memiliki korelasi dengan kreativitas belajar peserta didik, sedangkan nilai $r=$ 0,326 menunjukkan bahwa tidak terjadi korelasi positif antara perhatian orang tua terhadap kreativitas belajar peserta didik di MTs Muhammadiyah Julubori Kecamatan 
Palangga Kabupaten Gowa. Artinya tidak terdapat korelasi yang signifikan antara perhatian orang tua dan kreativitas belajar.

Berdasarkan tabel diperoleh angka $\mathrm{R}^{2}$ ( $\mathrm{R}$ Square) sebesar 0,106 atau (10,6\%). Hal ini menunjukkan bahwa persentase sumbangan perhatian orang tua terhadap kreativitas belajar sebesar $10,6 \%$ sedangkan sisanya sebesar $89,4 \%$ dipengaruhi atau dijelaskan oleh variabel lain yang tidak dimasukkan dalam model penelitian ini.

\section{SIMPULAN}

Berdasarkan hasil penelitian dan pembahasan, maka dapat ditarik kesimpulan sebagai berikut.

1. Gambaran perhatian orang tua peserta didik di MTs Muhammadiyah Julubori Kecamatan Palangga Kabupaten Gowa yaitu diperoleh rata-rata sebesar 33,64 berada pada kategori sedang.

2. Gambaran kreativitas belajar peserta didik di MTs Muhammadiyah Julubori Kecamatan Palangga Kabupaten Gowa yaitu diperoleh rata-rata sebesar 28,64 berada pada kategori sedang.

3. Berdasarkan hasil analisis inferensial perhatian orang tua terhadap kreativitas belajar peserta didik di MTs Muhammadiyah Julubori diperoleh bahwa pengaruh perhatian orang tua terhadap kreativitas belajar peserta didik dengan nilai signifikansi sebesar 0,052 artinya tidak memberikan pengaruh positif karena sig. > 0,05 .

\section{DAFTAR PUSTAKA}

Abdussalam, Muhammad Subhi. Langkah Mudah Gali Potensi Si Buah Hati Solo: Pustaka Iltizam, 2009.

Abolarin, Elizabeth Ebun. "The Influence of Prenatal, Home and Environmental factors on Learning Outcomes of Pre-Primary School Children”, IOSR Journal of Research \& Method in Education (IOSR-JRME) e-ISSN: 2320-7388,p-ISSN: 2320-737X Volume 4, Issue 6 Ver. III Nov - Dec. 2014.

Aeni, Nurul. Pengaruh Perhatian Orang Tua Terhadap Prestasi Belajar Siswa Pada Mata Pelajaran Sains Kelas V SDN 80/VIII Kecamatan Rimbo Ulu Kabupaten Tebo". Skripsi Jambi: FKIP, 2014.

Ahmadi, Abu. Psikologi Umum. Jakarta: PT Rineka Cipta, 1992.

Apriyati, Try. "Pengaruh Perhatian Orang Tua dan Minat Membaca Terhadap Hasil Belajar Bahasa Indonesia”. Skripsi Surakarta: FKIP, 2011.

Arikunto, Suharsimi. Manajemen Penelitian. Jakarta: Rineka Cipta, 2010. 
Baki, Nasir A. Metode Pembelajaran Agama Islam. Makassar: Alauddin University Press, 2012.

Beck, Joan. Asih Asah Asuh. Semarang: Dahara Prize, 1992.

Craft, Anna. Me-Refresh Imajinasi dan Kreativitas Anak-anak London: Cerdas Pustaka, 2000 .

Dalyono, Psikologi Pendidikan. Jakarta: Rineka Cipta, 2012.

Darajat, Zakiah. Ilmu Pendidikan Islam. Jakarta: Bumi Askara, 1996.

Darajat, Zakiah, dkk. Ilmu Pendidikan islam. Jakarta: PT Bumi Aksara, 2006.

Davis, Pamela E. dan Kean, "The Influence of Parent Education and Family Income on Child Achievement: The Indirect Role of Parental Expectations and the Home Environment”. Journal of Family Psychology Vol. 19, No. 2 Maret 2005.

Departemen Agama RI. Al-Quran dan Terjemahannya. (Cet X; Bandung: Diponegoro, 2010), h. 560.

Dimyati dan Mudjiono, Belajar dan Pembelajaran. Jakarta: PT Rineka Cipta, 2002.

Gitayana, "Pengaruh Lingkungan Keluarga dan Motivasi Orangtua Terhadap Prestasi Belajar Siswa”, Jurnal Pendidikan Teknik Otomotif_Universitas Muhammadiyah Purworejo, Vol.05 No.01. Januari 2017.

Jalaluddin. Psikologgi Agama. Jakarta: PT Raja Grafindo Persada, 1996.

Muhammad, Abu 'Abdillah bin Isma'il al-Bukhari. Sahih al-Bukhari, Juz V Kairo: Mathba'ah al-Salafiyah, $1400 \mathrm{H}$.

Munandar, Utami. Pengembangan Kreativitas Anak Berbakat. Jakarta: Pt Rineka Cipta, 1999.

Purwanto, M. Ngalim. Administrasi dan Supervisi Pendidikan. Bandung: Remaja Karya CV, 1988.

Rachmawati, Yeni dan Euis Kurniati. Strategi Pengembangan Kreativitas Pada Anak Usia Taman Kanak-kanak. Jakarta: Prenada Media Group, 2010.

Sjarkawi. Pembentukan Keprbadian anak (Peran Moral Intelektual, Emosional, dan Sosial Sebagai Wujud Integras Membangun Jati Diri). Jakarta: PT Bumi Aksara, 2008 .

Slameto, Belajar dan Faktor-faktor yang Mempengaruhinya. Jakarta: PT Rineka Cipta, 1995.

Sudjana, Nana dan Ibrahim, Penelitian dan Penilaian Pendididkan. Bandung: Sinar Baru Offset, 1989. 
Sugiyono, Metode Penelitian Kuantitatif, Kuantitatif, dan $R \& D$ Bandung: Alfabeta, 2013.

\section{------------. Statistika untuk Penelitian. Bandung: Alfabeta, 2013.}

Sukmadinata, Nana Saodih. Metode Penelitian Pendidikan. Bandung: PT Remaja Rosdakarya, 2011.

Sulaiman,Umar. Analisis Pengetahuan, Sikap, dan Perilaku. Makassar: Alauddin University Press, 2011.

Suryabrata, Sumadi. Psikologi Pendidikan. Jakarta: PT Raja Grafindo Persada, 2002.

Syah, Muhibbin. Psikologi Belajar. Jakarta: Raja Grafindo Persada, 2006.

Syamsuddin, Sistem Pengasuhan Orang Tua Agar Anak Berkualitas Makassar: Alauddin University Press, 2014.

Syarifudin, Tatang. Landasan Pendidikan. Jakarta: Direktorat Jenderal Pendidikan Islam Departemen Agama RI, 2009.

Taniredja, Tukiran dan Hidayati Mustafidah, Penelitian Kuantitatif . Bandung: Penerbit Alfabeta, 2011.

Tim Penyusun Kamus Pusat Pembinaan dan Pengembangan Bahasa. Kamus Besar Bahasa Indonesia. Jakarta: Balai Pustaka, 1988.

Ummah, Ade Farhatul. "Sikap Otoriter Orang Tua dan Pengaruhnya Terhadap motivasi Belajar Siswa di MTs Al-Hidayah Jatiasih Kota Bekasi" Jurnal Pendidikan Agama Islam Universitas Islam Negeri Syarif Hidayatullah, Vol. 05 No. 01 Februari 2017.

Universitas Islam Negeri Alauddin, Pedoman Penulisan Karya Tulis Ilmiah: Makalah, Skripsi, Tesis, Disertasi, dan Laporan Penelitian. Makassar: Alauddin Press, 2013.

Yusanto, M. Ismail dkk. Menggagas Pendidikan Islam. Bogor: Al Azhar Press ,2014. 